University of Nebraska - Lincoln

DigitalCommons@University of Nebraska - Lincoln

Faculty Publications: Department of Entomology

6-1989

\title{
Effect of Host Plant on the Level of Virulence of Nilaparvata lugens (Homoptera: Delphacidae) on Rice Cultivars
}

\author{
A. H. Bahagiawati \\ International Rice Research Institute \\ E. A. Heinrichs \\ International Rice Research Institute, eheinrichs2@unl.edu \\ F. G. Medrano \\ International Rice Research Institute
}

Follow this and additional works at: https://digitalcommons.unl.edu/entomologyfacpub

Part of the Agriculture Commons, and the Entomology Commons

Bahagiawati, A. H.; Heinrichs, E. A.; and Medrano, F. G., "Effect of Host Plant on the Level of Virulence of Nilaparvata lugens (Homoptera: Delphacidae) on Rice Cultivars" (1989). Faculty Publications: Department of Entomology. 846.

https://digitalcommons.unl.edu/entomologyfacpub/846

This Article is brought to you for free and open access by the Entomology, Department of at DigitalCommons@University of Nebraska - Lincoln. It has been accepted for inclusion in Faculty Publications: Department of Entomology by an authorized administrator of DigitalCommons@University of Nebraska - Lincoln. 


\title{
Effect of Host Plant on the Level of Virulence of Nilaparvata lugens (Homoptera: Delphacidae) on Rice Cultivars
}

\author{
A. H. Bahagiawati, ${ }^{1}$ E. A. Heinrichs, ${ }^{2}$ and F. G. Medrano \\ International Rice Research Institute, Manila, Philippines \\ 1. Current address - Bogor Institute for Food Crops, Bogor, Indonesia \\ 2. Current address - Department of Entomology, Louisiana State University Agricultural Center, 402 Life \\ Sciences Building, Louisiana State University, Baton Rouge, LA 70803
}

\begin{abstract}
The virulence of a planthopper, Nilaparvata lugens (Stål) biotype 3, reared on rice cultivar ASD7and of N. lugens colonies collected on Mindanao Island in the southern Philippines and reared on the widely grown commercial cultivars IR36 and IR42 was compared. Based on plant damage, insect weight, population growth, and feeding activity, the Mindanao N. lugens colonies reared on IR36 and IR42 were more virulent than biotype 3, although ASD7, IR36, and IR42 have the bph2 gene for $N$. lugens resistance. These results clearly indicate that in the screening of breeding lines for resistance to $N$. lugens, it is important to use insect populations reared on cultivars similar to those grown in farmers' fields. Failure to do so may result in the release of a cultivar that is susceptible to the N. lugens field population.
\end{abstract}

Keywords: Insecta, host plants, virulence, Nilaparvata lugens

The planthopper Nilaparvata lugens (Stål) was formerly a minor pest of rice in South and Southeast Asia but has become a major problem throughout those regions during the past decade (Dyck \& Thomas 1979). It causes economic damage by removing phloem sap during feeding (Sogawa \& Cheng 1979) and by vectoring grassy stunt virus (Rivera et al. 1966) and ragged stunt virus (Ling et al. 1978). Widespread adoption of high-yielding cultivars 
susceptible to N. lugens, applications of high levels of nitrogen fertilizers, continuous cropping, staggered planting, and nonjudicious use of insecticides have been reported as causes for increased N. lugens populations (Chelliah \& Heinrichs 1984).

Plant resistance, which is relatively stable, cheap, causes no environmental pollution, and is generally compatible with other tactics, has been considered as a major control strategy against several pests (Oka 1983). However, continuous planting of highly resistant rice cultivars with major genes contributing vertical resistance induced selection of $N$. lugens biotypes capable of damaging resistant cultivars (Pathak \& Khush 1979). After being grown for about $2 \mathrm{yr}$, cultivars with the Bph1 gene, particularly IR26, were replaced by IR36 and IR42 with the $b p h 2$ gene for resistance. IR36 and IR42 currently are grown on more than 13 million ha in Southeast Asia (International Rice Research Institute 1983). After years of intensive planting, IR36 and IR42 were reported to be damaged by N. lugens in northern Sumatra and central Sulawesi, Indonesia (Oka \& Bahagiawati 1983) and in Mindanao, Philippines (Medrano \& Heinrichs 1985a). IR36, IR42, and ASD7 have the $b p h 2$ gene for $N$. lugens resistance. For this reason, insects reared on IR36, IR42, and ASD7 have generally been considered to be of the same biotype. N. lugens reared on ASD7 in the greenhouse has been named as biotype 3 and is used in screening to identify resistant breeding lines. Lines resistant to biotype 3 reared on ASD7 have generally been considered to have a similar level of resistance to $N$. lugens populations developing on IR36 and IR42. We conducted greenhouse and laboratory tests to determine whether the N. lugens reared on IR36, IR42, ASD7 actually have the same level of virulence as measured by selected parameters.

\section{Materials and Methods}

About 200 gravid females of $N$. lugens were collected from rice fields in Mindanao in November 1982 and reared for three generations on plants of the susceptible rice cultivar "Taichung Native 1" (TN1) in the greenhouse at the International Rice Research Institute. Half of the population was then reared on potted IR36 plants (30-50 d old) and the other half on IR42 plants of the same age (Medrano \& Heinrichs 1985b). The populations were named M36 and M42 (Mindanao population reared on IR36 and IR42, respectively). The 22nd-generation nymphs of M36 and M42 and the 80th generation on ASD7 were used as test insects in this study. The ASD7 colony named as biotype 3 originated from a field collection on Luzon Island, Philippines, and had been reared in the greenhouse for about 8 yr. Cultivars with the Bph1 gene for resistance (IR46), bph2 gene (ASD7, IR36, and IR42), $B p h 3$ gene (IR62), and no gene for resistance (susceptible IR22) were tested against the three $N$. lugens populations. All tests were conducted under greenhouse conditions at a temperature of $20-30^{\circ} \mathrm{C}$ and a relative humidity of $70-90 \%$.

\section{Plant Damage Ratings}

Plant damage ratings were determined in a standard seedbox screening test and a modified seedbox screening test (Heinrichs et al. 1985). In the standard test, the released insects caused the plant damage, whereas in the modified test the second generation caused the damage. The modified test is used to identify cultivars which have field resistance (resistant as older plants but susceptible as seedlings) (Velusamy et al. 1986). The experiment 
was conducted in three replications with treatments arranged in a split split-plot design (Gomez \& Gomez 1976). The two screening methods (standard test and modified test) served as main plots, $N$. lugens colonies as subplots, and cultivars as sub-subplots.

Two wooden seedboxes ( 60 by 40 by $7 \mathrm{~cm}$ ), one for the standard test and the other for the modified test, were used for each replication. The seedboxes were filled with paddy soil ( $5 \mathrm{~cm}$ deep) which was fertilized with $25 \mathrm{ml}$ of $20 \%$ ammonium sulfate fertilizer. The fertilizer solution was prepared by dissolving $250 \mathrm{~g}$ of ammonium sulfate fertilizer (containing $21 \%$ nitrogen) in $750 \mathrm{ml}$ water. Each seedbox was divided across its length into three subplots on which the three insect colonies were randomly distributed. In a subplot, six rows $4 \mathrm{~cm}$ apart and $20 \mathrm{~cm}$ long were prepared where the six cultivars were randomly sown.

Sowing in the modified test was done $3 \mathrm{~d}$ ahead of the standard. When the seedlings were $7 \mathrm{~d}$ old in the standard test and $10 \mathrm{~d}$ old in the modified test, weeds were removed from all plots, and seedlings per row were counted. Each plot was then enclosed with a Mylar film cage ( 60 by 40 by $15 \mathrm{~cm}$ ) with the top and two side windows covered with nylon mesh screen for ventilation. The subplots were separated by Mylar film so that the insect colonies were kept separate. The seedlings in the boxes were infested by releasing into each cage 5-d-old nymphs at the rate of three and eight nymphs per seedling for the standard test and modified test, respectively. In the modified test, $25 \mathrm{ml}$ of the fertilizer solution were again applied in each seedbox at 18 and $30 \mathrm{~d}$ after sowing.

Visual scoring of plant damage was based on a 0-9 scale according to the Standard Evaluation System for Rice (International Rice Research Institute 1979). Damage grading started when IR22 (susceptible check cultivar) was rated 7 or 9 and ratings were repeated twice at 1-d intervals in the standard test and at 2-d intervals in the modified test. Final ratings were based on the average of the ratings. Damage grades ranging from 0 to 3.9 were rated as resistant, 4.0 to 6.9 as moderately resistant, and 7 to 9 as susceptible.

\section{Survival, Insect Weight, and Population Growth}

Five $\mathrm{ml}$ of fertilizer solution was thoroughly mixed in $2.5 \mathrm{~kg}$ paddy soil placed into a plastic container (14 cm diameter, $15 \mathrm{~cm}$ high). Three 5-d-old seedlings of one cultivar were planted in each container. Each cultivar was planted in four plastic containers representing four replications, and containers were arranged in a split-plot design; cultivars served as main plots and insect colonies as subplots. At $20 \mathrm{~d}$ after transplanting, the plants in each container were enclosed with a Mylar film cage $(13 \mathrm{~cm}$ diameter, $90 \mathrm{~cm}$ high). Test cultivars (except IR62, the resistant check) were infested with 15 newly hatched nymphs per cage. IR62 was infested with 30 nymphs per cage. Eighteen days after infestation, the surviving insects in each cage were counted, collected, and placed in individual vials. After each collection, two randomly selected pairs (male and female) of adults were put back on fresh plants of the same cultivar on which they were reared. The remaining male insects were discarded, and the females were oven-dried at $55^{\circ} \mathrm{C}$ for $24 \mathrm{~h}$ and weighed on a Mettler ME-30 balance (Mettler Instrument Corporation, Highstown, New Jersey) ( $1 \mu \mathrm{g}$ sensitivity). At $21 \mathrm{~d}$ after reinfestation with adults, the $F_{1}$ progenies of the two pairs in individual cages were counted, collected in vials, oven dried, and weighed on a Mettler ME-30 balance. 


\section{Honeydew Excretion}

The amount of insect feeding was measured using the bromocresol green filter paper method (Pathak \& Heinrichs 1982). Five 5-d-old plants of each cultivar were planted individually in clay pots $(7 \mathrm{~cm}$ diameter, $5 \mathrm{~cm}$ high). Each pot served as one replicate. When the plants were $35 \mathrm{~d}$ old, a honeydew collection chamber (Paguia et al. 1980) was attached to each plant, and the pots were arranged in a split-plot design with cultivars as the main plot and colonies as subplots. Then five 3-d-old female N. lugens starved for $5 \mathrm{~h}$ were released into each chamber. After feeding for $24 \mathrm{~h}$, the filter papers were collected. The amount of honeydew excreted was determined by measuring the area of honeydew spots on the filter paper. This was done by tracing the honeydew spots on Mylar film sheets (7.5 by $7.5 \mathrm{~cm}$ ) with a black marking pen, and the blackened areas were individually passed through an automatic area meter which registered the area in square millimeters.

\section{Results}

\section{Plant Damage Ratings}

Responses of the various cultivars to the three insect colonies were generally similar in the two seedbox screening tests (Fig. 1). IR62 had a high to moderate level of resistance to all three N. lugens colonies in both the standard and modified tests. IR46 in the standard test responded similarly to the three insect colonies, whereas in the modified test it was significantly most resistant to biotype 3. IR36 and IR42 were susceptible to M36 and M42 in both tests, whereas they were moderately resistant to biotype 3 in the standard and highly resistant in the modified test. ASD7 and IR22 were equally susceptible to the three colonies in both tests.

Based on the damage ratings, M36 and M42 are more virulent on IR36 and IR42 than is biotype 3. The standard and the modified tests indicate that IR36 and IR42 have resistance to biotype 3 but not to M36 or M42. The level of resistance, however, is higher in the modified test, indicating some field resistance to biotype 3 . 

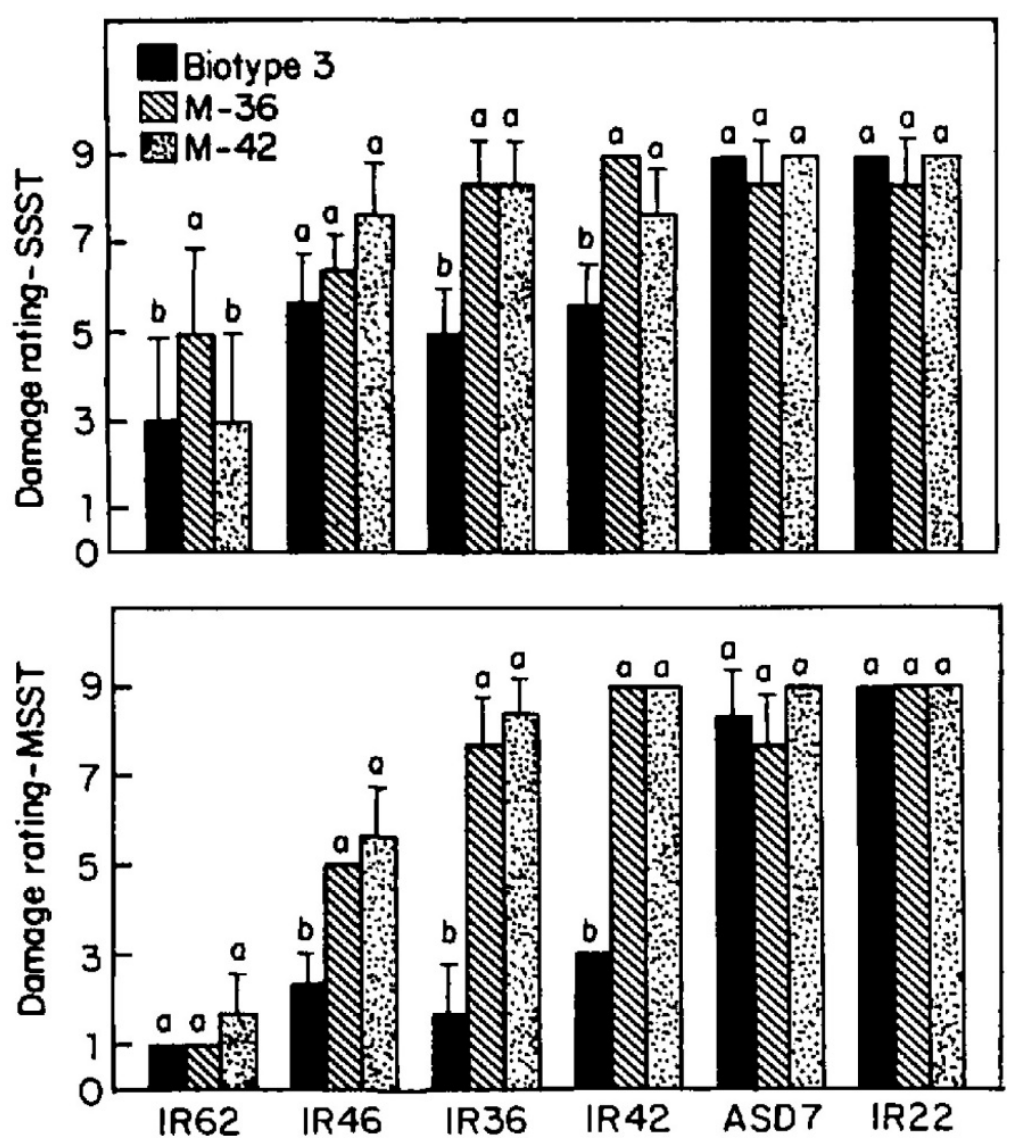

Figure 1. Damage ratings of selected rice cultivarswhen infested with N. lugens biotype 3 and the M36 and M42 colonies in the standard (SSST) and modified seedbox screening tests (MSST).For each cultivar, columns with a common letter are not significantly different $(P<0.05$, Duncan's multiple range test). Vertical bars indicate standard errors.

\section{Survival, Insect Weight, and Population Growth}

Although survival of all colonies was lowest on IR62, survival of N. lugens biotype 3, M36, and M42 colonies did not significantly differ $(P<0.05)$ on the test cultivars (Fig. 2). However, the number of $\mathrm{F}_{1}$ progeny significantly differed among colonies (Fig. 3A). The number of M36 and M42 was significantly higher than those of biotype 3 on IR36 and IR42 plants. It is important to note that the M36 colony had a significantly higher population on IR36 plants than did the other two insect colonies. Likewise, biotype 3 population growth was highest, although not significantly different from M42, on ASD7. No significant difference was observed between the number of $\mathrm{F}_{1}$ progeny of M36 and M42 colonies on IR62, IR42, and IR22 or on ASD7. The three insect colonies developed very low populations on resistant IR62 plants. 


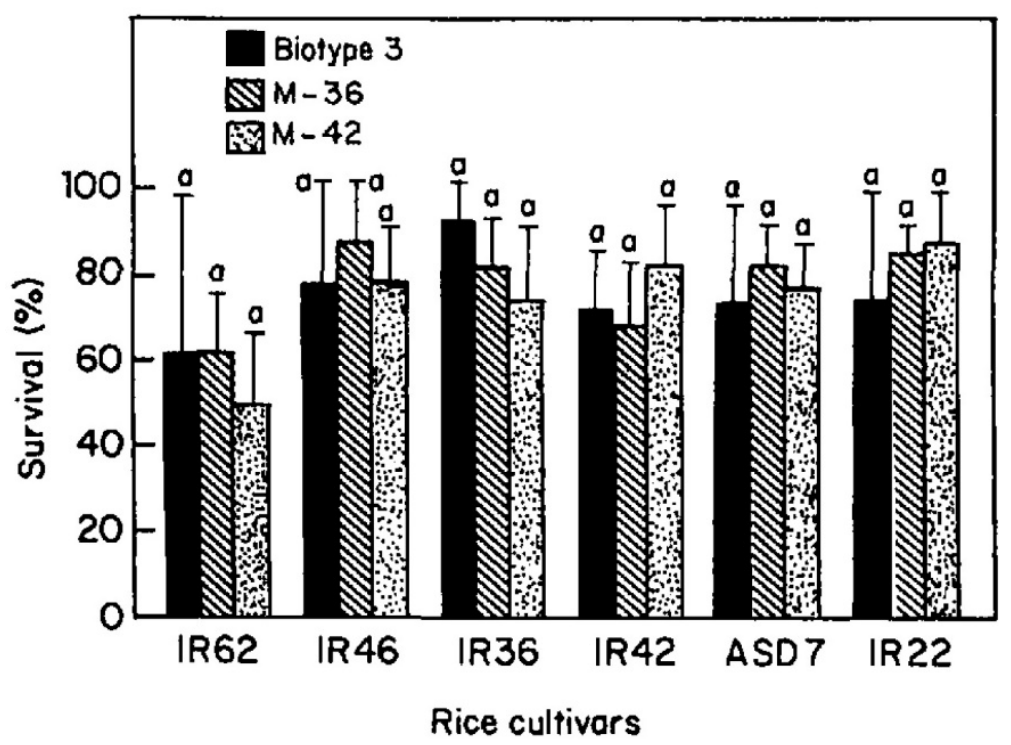

Figure 2. Survival of N. lugens biotype 3 and the M36 and M42 colonies when reared on selected rice cultivars. Columns within a cultivar with the same letter are not significantly different $(P<0.05$, Duncan's multiple range test). Vertical bars indicate standard errors.

The body weight of $N$. lugens female adults that developed on test cultivars differed significantly among the insect colonies (Fig. 3B). The M36 and M42 colonies on IR36 and IR42 plants had significantly higher body weight than biotype 3 on the same cultivars. Biotype 3 was heavier than the M42 colony on ASD7 plants. No significant differences were noted in weights of the three insect colonies on susceptible IR22 or on the resistant IR62 cultivar.

Individual body weights of the $\mathrm{F}_{1}$ progenies (which consisted of nymphs and adults) significantly differed among the test colonies within cultivars (Fig. 3C). The M36 and M42 insects were significantly heavier than biotype 3 on IR36 and IR42 plants because they were adults. Likewise, M36 insects were significantly heavier than biotype 3 insects on IR62 and IR46 plants. No significant difference in body weight was noted among the three insect colonies on ASD7 and IR22 plants. 

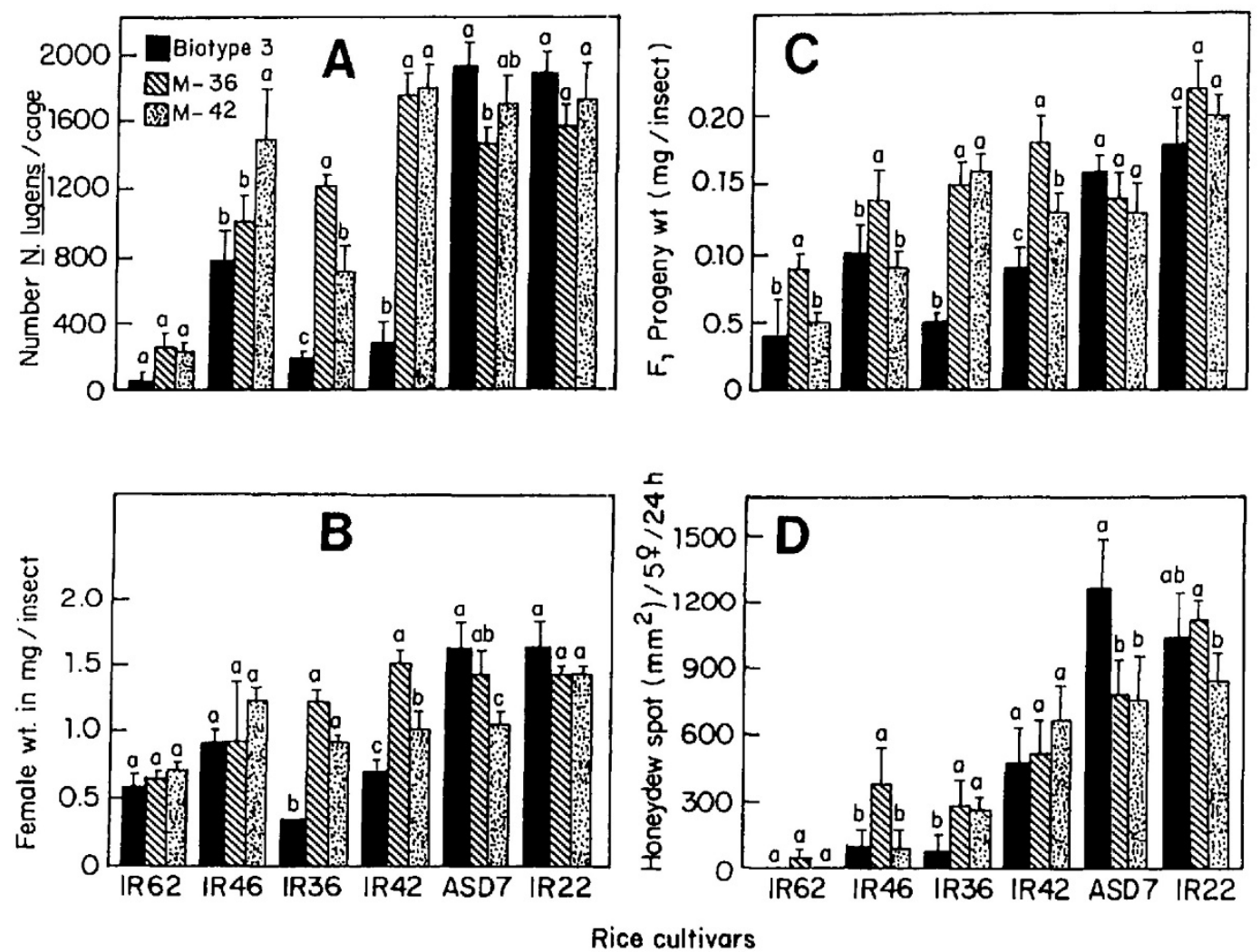

Figure 3. Population growth (A), female weight (B), $\mathrm{F}_{1}$ progeny weight (C), and area of honeydew excreted (D) by N. lugens biotype 3 and M36 and M42 colonies on selected rice cultivars. For each parameter, columns within a cultivar with the same letter are not significantly different $(P<0.05$, Duncan's multiple range test). Vertical bars indicate standard errors.

\section{Honeydew Excretion}

The amount of honeydew excreted by M36 and M42 adults was significantly greater than that of biotype 3 on IR36 plants (Fig. 2D). The M36 adults excreted significantly more honeydew than M42 and biotype 3 on IR46 plants. On the other hand, biotype 3 excreted significantly more honeydew than M36 and M42 insects on ASD7 plants. Very little honeydew was excreted by the three insect colonies on resistant IR62 plants; however, a large amount was excreted on susceptible ASD7 and IR22 plants.

\section{Discussion}

The significantly greater damage on IR46, IR36, and IR42 by M36 and M42 colonies indicated greater virulence of these colonies compared with biotype 3 in terms of damaging plants with Bph1 and bph 2 resistance genes. The two Mindanao colonies could be considered of equal virulence because their damage on each of the above cultivars did not differ significantly. 
Scoring of plant damage in the standard and modified tests occurred when IR22, the susceptible cultivar common to both screening methods, was killed. The generally higher degree of damage on moderately resistant genotypes in the standard test could be attributed to the inability of young seedlings to exhibit resistance to a severe infestation.

The insignificant difference in survival among the three N. lugens colonies on the different test materials confirmed previous studies where early instars could survive and develop to adults on resistant and moderately resistant plants (Medrano \& Heinrichs 1980). However, their body weight and reproduction were affected as previously reported by $\mathrm{Wu}$ et al. (1986). The M36 and M42 female adults were significantly heavier and produced higher populations and heavier individual $F_{1}$ progenies compared with biotype 3 when reared on IR36 and IR42 plants. Also, these two Mindanao colonies excreted significantly more honeydew than biotype 3 on IR36 plants. These observations indicate that biotype 3 is of weaker virulence than the M36 and M42 colonies on these cultivars. This study supports the observations of Claridge et al. (1982), where N. lugens colonies collected from a wild rice species, traditional cultivars, and modern improved cultivars in Sri Lankan fields were most closely adapted to the cultivars from which they were collected when tested for virulence in the greenhouse in England.

IR36 and IR42 have been grown extensively in farmers' fields in the Philippines. Thus, the use of populations such as M36 and M42 that kill these cultivars would be appropriate in searching for rice-breeding lines that are resistant to these $N$. lugens populations which may develop in the field. When one of these populations begins damaging IR36 or IR42 in farmers' fields, cultivars resistant to these populations can be released.

ASD7 has been used as the host plant to rear biotype 3. It has been assumed that because the major gene for N. lugens resistance in ASD7 (bph2) is the same as in IR36 and IR42, biotype 3 can be used to identify breeding lines resistant to the biotype expected to develop on IR36 and IR42. However, this study clearly indicates that N. lugens used for screening breeding lines should be reared on the same cultivar that is grown in farmers' fields if we want to identify sources that are resistant to the biotype expected to develop on that cultivar.

\section{References Cited}

Chelliah, S. \& E. A. Heinrichs. 1984. Factors contributing to rice brown plant hopper resurgence, pp. 107-115. In Judicious and efficient use of insecticides on rice. International Rice Research Institute, Los Baños, Philippines.

Claridge, M. F., J. den Hollander \& I. Furet. 1982. Adaptations of brown planthopper (Nilaparvata lugens) populations to rice varieties in Sri Lanka. Entomol. Exp. Appl. 32: 222-226.

Dyck, V. A. \& B. Thomas. 1979. The brown planthopper problem, pp. 3-17. In Brown planthopper: threat to rice production in Asia. International Rice Research Institute, Los Baños, Philippines.

Gomez, K. A. \& A. A. Gomez. 1976. Statistical procedures for agricultural research. Wiley, New York.

Heinrichs, E. A., H. Rapusas \& F. Medrano. 1985. Genetic evaluation for insect resistance in rice. International Rice Research Institute, Los Baños, Philippines.

International Rice Research Institute. 1979. Standard evaluation system for rice, 2nd ed. International Rice Research Institute, Los Baños, Philippines. 
International Rice Research Institute. 1983. IR36, the world's most popular rice. International Rice Research Institute, Los Baños, Philippines.

Ling, K. C., E. R. Tiongco \& V. M. Aquino. 1978. Rice ragged stunt: a new virus disease. Plant Dis. Rep. 62: 701-705.

Medrano, F. G. \& E. A. Heinrichs. 1980. Influence of the stage of the brown planthopper Nilaparvata lugens and plant age on insect survival on resistant varieties. Int. Rice Res. Newsl. 5(3): 8.

Medrano, F. G. \& E. A. Heinrichs. 1985a. Response of resistant rices to brown planthopper (BPH) collected in Mindanao, Philippines. Int. Rice Res. Newsl. 10(6): 14-15.

Medrano, F. G. \& E. A. Heinrichs. 1985b. Nilaparvata lugens. In P. Singh \& R. F. Moore [eds.], Handbook of insect rearing, vol. 1. Elsevier, New York.

Oka, I. N. 1983. The potential for the integration of plant resistance, agronomic, biological, physi$\mathrm{cal} /$ mechanical techniques, and pesticides for pest control in farming systems, pp. 173-184. In Chemistry and world supplies: the new frontiers. CHEMRAWN II. Pergamon, Oxford.

Oka, I. N, \& A. H. Bahagiawati. 1983. Development of a new biotype of the rice brown planthopper Nilaparvata lugens in North Sumatra, Indonesia. Pusat Penelitian dan Pengembarigan Tanornan Pangan Seri Mahalah Penelitian No. 1. Bogor, Indonesia.

Paguia, P., M. D. Pathak \& E. A. Heinrichs. 1980. Honeydew excretion measurement techniques for determining feeding activity of biotypes of Nilaparvata lugens on rice varieties. J. Econ. Entomol. 73: 35-40.

Pathak, M. D. \& G. S. Khush. 1979. Studies of varietal resistance in rice to the brown planthopper at the International Rice Research Institute, pp. 273-274. In Brown planthopper: threat to rice production in Asia. International Rice Research Institute, Los Baños, Philippines.

Pathak, P. K. \& E. A. Heinrichs. 1982. Bromocresol green indicator for measuring feeding activity of Nilaparvata lugens on rice varieties. Philipp. Entomol. 5: 195-198.

Rivera, C. T., S. H. Ou \& T. T. Iida. 1966. Grassy stunt disease of rice and its transmission by the brown planthopper, Nilaparvata lugens Stål. Plant Dis. Rep. 50: 453-456.

Sogawa, K. \& C. H. Cheng. 1979. Economic thresholds, nature of damage, and losses caused by the brown planthopper in Asia, pp. 125-142. In Brown planthopper: threat to rice production in Asia. International Rice Research Institute, Los Baños, Philippines.

Velusamy, R., E. A. Heinrichs \& F. G. Medrano. 1986. Greenhouse techniques to identify field resistance to the brown planthopper, Nilaparvata lugens (Stål) (Homoptera; Delphacidae) in rice cultivars. Crop Protect. 5: 328-333.

Wu, Jung-Tsung, E. A. Heinrichs \& F. G. Medrano. 1986. Resistance of wild rices, Oryza spp., to the brown planthopper, Nilaparvata lugens (Homoptera: Delphacidae). Environ. Entomol. 15: 648-653. 